\title{
PENERAPAN PENDEKATAN PROBLEM BASED LEARNING UNTUK MENINGKATKAN KEMAMPUAN BERPIKIR KREATIF MATEMATIK SISWA SMA
}

\author{
Adi Nurjaman $^{1 \bowtie}$ dan Indah Puspita Sari $^{2}$ \\ ${ }^{1,2}$ Prodi Pendidikan Matematika, IKIP Siliwangi
}

\begin{abstract}
Info Artikel Abstract Sejarah Artikel:

This study aims to examine the discussion and increase the creative thinking skills of high school

Diterima 8 Nov 2019

Direvisi 18 Nov 2019

Disetujui 18 Nov 2019 students who use problem-based learning. The method used in this study is quasi-experimental. The population in this study were all high school students in West Bandung Regency while the sample was chosen by two classes of XI Senior High School in Ngamprah. The instrument in this study consisted of a descriptive type test consisting of five items with indicators of mathematical creative thinking ability. Research data were analyzed quantitatively using statistical tests (t-test). The results of his research are 1) Achievement of creative thinking abilities of high school students whose spenders use Problem Based Learning are better than high school students who use ordinary learning, with

Keywords: Problem Based Learning,

Creative Thinking categories for creative thinking abilities. 2) Increasing the creative thinking ability of high school students whose learners use Problem Based Learning is better than high school students who use ordinary learning, with categories for moderate creative thinking abilities.
\end{abstract}

Paper type:

Research paper

\begin{abstract}
Abstrak
Penelitian ini bertujuan untuk menelaah pencapaian dan peningkatan kemampuan berpikir kreatif matematik siswa SMA yang pembelajarannya menggunakan pendekatan Problem-Based Learning dibandingkan dengan yang menggunakan pembelajaran biasa. Metode yang digunakan dalam penelitian ini adalah metode kuasi-eksperimen. Populasi dalam penelitian ini adalah seluruh siswa SMA di Kabupaten Bandung Barat sedangkan sampel dipilih dua kelas XI SMAN di Ngamprah. Instrumen dalam penelitian ini berupa tes tipe uraian yang terdiri dari lima butir soal dengan indikator kemampuan berpikir kreatif matematik. Data hasil penelitian dianalisis secara kuantitatif dengan menggunakan uji statistik (uji-t). Adapun hasil penelitiannya adalah 1) Pencapaian kemampuan berpikir kreatif matematik siswa SMA yang pembelajaranya menggunakan pendekatan ProblemBased Learning lebih baik daripada siswa SMA yang menggunakan pembelajaran biasa, dengan kategori untuk kemampuan berpikir kreatif sedang. 2) Peningkatan kemampuan berpikir kreatif matematik siswa SMA yang pembelajaranya menggunakan pendekatan Problem-Based Learning lebih baik daripada siswa SMA yang menggunakan pembelajaran biasa, dengan kategori untuk kemampuan berpikir kreatif sedang.
\end{abstract}

(C) 2019 Universitas Muria Kudus

\footnotetext{
Alamat korespondensi:

Program Studi Pendidikan Matematika

Fakultas Keguruan dan Ilmu Pendidikan Universitas Muria Kudus

Kampus UMK Gondangmanis, Bae Kudus Gd. L. It I PO. BOX 53 Kudus

Tlp (0291) 438229 ex.147 Fax. (0291) 437198

E-mail: hendrialfianto@gmail.com
}

p-ISSN 2615-4196 


\section{PENDAHULUAN}

Pendidikan merupakan salah satu upaya untuk menghasilkan sumber daya manusia yang unggul dan berkualitas. Selain itu, pendidikan dapat menghasilkan generasi-generasi muda yang kreatif. Kreatif menurut Kamus Besar Bahasa Indonesia adalah kemampuan untuk menciptakan. Berpikir kreatif dapat diartikan juga sebagai suatu cara untuk mengembangkan dan melihat suatu masalah dari perspektif yang berbeda. Brown (Lince, 2016) strategi untuk mengembangkan serta menemukan ide-ide baru siswa adalah dengan cara melatih kemampuan berfikir kreatif. Selain itu berpikir kreatif dapat diartikan sebagai aktivitas mental seseorang dalam membangun ide baru yang mereka miliki. Menurut Bartsch (Rohaeti, Nurjaman, Sari, Bernard, \& Hidayat, 2019) Berpikir kreatif merupakan aktivitas mental yang membutuhkan ketekunan, disiplin diri, dan perhatian. Aktivitas mental yang dimaksud antara lain: (1) mengajukan pertanyaan, (2) informasi baru dan ide-ide yang tidak biasa dengan pikiran terbuka, (3) membangun interelasi terutama hal-hal yang berbeda, (4) saling berhubungan secara bebas, 5) menyiratkan imajinasi di setiap situasi sehingga menghasilkan hal yang berbeda, (6) mendengarkan intuisi. Kemampuan berpikir kreatif ini penting dimiliki oleh siswa karena secara umum berpikir kreatif merupakan bagian dari keterampilan hidup yang diperlukan oleh siswa dalam kemajuan IPTEK.

Kemampuan berpikir kreatif menurut Sumarmo (Nurjaman \& Sari, 2017), meliputi kelancaran, keluwesan, keaslian dan elaborasi. Karakteristik kelancaran (fluency) meliputi: 1) mencetuskan banyak ide, jawaban, penyelesaian masalah, dan pertanyaan dengan lancar, 2) memberikan banyak cara atau saran untuk melakukan berbagai hal, 3) selalu memikirkan lebih dari satu jawaban. Karakteristik keluwesan (flexibility) meliputi: 1) menghasilkan gagasan, jawaban, atau pertanyaan yang bervariasi, 2) melihat suatu masalah dari sudut pandang yang berbeda, 3) mencari banyak alternatif atau arah yang berbeda-beda, dan 4) mengubah cara pendekatan atau cara pemikiran. Karakteristik keaslian (originality) meliputi: 1) melahirkan ungkapan yang baru dan unik, 2) memikirkan cara yang tidak lazim, dan 3) membuat kombinasi yang tidak lazim dari bagianbagiannya. Karakteristik elaborasi (elaboration) meliputi: 1) memperkaya dan mengembangkan suatu gagasan atau produk, 2) menambah atau memperinci detil-detil dari suatu obyek, gagasan, atau situasi sehingga menjadi lebih menarik.

Kemampuan berpikir kreatif siswa ini tidak akan berkembangkan dengan baik jika dalam proses pembelajaran guru tidak melibatkan siswa secara aktif. Oleh karena itu, dibutuhkan pendekatan pembelajaran yang dapat memfasilitasi siswa untuk terlibat secara aktif. Salah satu alternatif pembelajarannya yaitu dengan menggunakan pendekatan Problem Based Learning. Pembelajaran berbasis masalah (Problem-Based Learning), mula-mula dikembangkan pada sekolah kedokteran di Ontario, Kanada pada 1960-an. Strategi ini pada mulanya dikembangkan sebagai respon atas fakta bahwa para dokter muda yang baru lulus sangat kaya akan pengetahuan, tetapi kurang memiliki keterampilan untuk memanfaatkannya dalam kehidupan sehari-hari. Perkembangan selanjutnya, Problem-Based Learning secara luas diterapkan di berbagai mata pelajaran di sekolah maupun perguruan tinggi.

Problem-Based Learning merupakan suatu pendekatan pembelajaran yang menggunakan masalah dalam kehidupan seharihari sebagai langkah awal dalam mengumpulkan dan mengintegrasikan pengetahuan baru. Menurut Arends (Hosnan, 2014), pendekatan Problem-Based Learning merupakan suatu pendekatan pembelajaran yang menekankan siswa pada masalah autentik sehingga siswa dapat menyusun pengetahuannya sendiri, mengembangkan keterampilan yang lebih tinggi dan inkuiri, memandirikan siswa dan meningkatkan kepercayaan diri sendiri. Adapun pengertian yang lain, menurut (Barrows \& Tamblyn, 1980) Problem-Based Learning merupakan strategi belajar yang membelajarkan seseorang untuk memecahkan masalah dan merefleksikannya dengan pengalaman mereka dalam kehidupan sehari-hari.

Adapun langkah-langkah pembelajaran dengan menggunakan pendekatan Problem Based Learning menurut Yazdani (Arief \& Sudin, 2016) yang merujuk pada Arends, yaitu sebagai berikut. Tahap orientasi yaitu mengorientasikan siswa pada masalah, kemudian tahap organisasi yaitu mengorganisasikan siswa untuk belajar, dilanjutkan dengan tahap inkuiri yaitu membantu penyelidikan mandiri dan kelompok, selanjutnya tahap presentasi yaitu mengembangkan dan menyajikan hasil karya serta memamerkannya, dan tahap terakhir yaitu tahap analisis dan evaluasi, yaitu menganalisis 
dan mengevaluasi proses pemecahan masalah. Sejalan dengan langkah-langkah Problem-Based Learning menurut (Hosnan, 2014) yaitu: (1) Orientasi siswa terhadap masalah. Pada tahap ini, guru harus menjelaskan tujuan pembelajaran dan aktivitas yang akan dilakukan agar siswa tahu apa tujuan utama pembelajaran, apa permasalahan yang akan dibahas, bagaimana guru akan mengevaluasi proses pembelajaran. Hal ini untuk memberi konsep dasar kepada siswa. Guru harus bisa memberikan motivasi siswa untuk terlibat aktif dalam pemecahan masalah yang dipilih. (2) Mengorganisasikan siswa. Pada tahap ini, guru membantu siswa mendefinisikan dan mengorganisasikan tugas belajar yang berhubungan dengan masalah yang telah diorientasi, misalnya membantu siswa membentuk kelompok kecil, membantu siswa membaca masalah yang ditemukan pada tahap sebelumnya, kemudian mencoba untuk membuat hipotesis atas masalah yang ditemukan tersebut. (3) Membimbing penyelidikan individu dan kelompok. Pada tahap ini, guru mendorong siswa untuk mengumpulkan informasi sebanyakbanyaknya, melaksanakan eksperimen, menciptakan dan membagikan ide mereka sendiri untuk mendapatkan penjelasan dan pemecahan masalah. (4) Mengembangkan dan menyajikan hasil karya. Pada tahap ini guru membantu siswa dalam menganalisis data yang telah terkumpul pada tahap sebelumnya, sesuaikah data dengan masalah yang telah dirumuskan. Siswa memberi argumen terhadap jawaban pemecahan masalah. Karya bisa dibuat dalam bentuk laporan, video, atau presentasi. (5) Menganalisis dan mengevaluasi proses pemecahan masalah. Pada tahap ini, guru meminta siswa untuk merekonstruksi pemikiran dan aktivitas yang telah dilakukan selama proses kegiatan belajarnya. Guru dan siswa menganalisis dan mengevaluasi terhadap pemecahan masalah yang dipresentasikan setiap kelompok.

Penelitian yang akan dilakukan di salah satu SMA di Kabupaten Bandung Barat ini bertujuan untuk menelaah pencapaian dan peningkatan kemampuan berpikir kreatif matematik siswa SMA yang pembelajarannya menggunakan pendekatan Problem-Based Learning dibandingkan dengan yang menggunakan pembelajaran biasa. Berdasarkan hasil studi pendahuluan yang telah dilakukan peneliti sebelumnya di sekolah tersebut, kemampuan berpikir kreatif siswa masih rendah. Hal tersebut sejalan dengan hasil penelitian yang telah dilakukan oleh Ayuni, Firmansyah,
Senjayawati dan Maya (2018:147) yang menunjukan bahwa di salah satu sekolah menengah di Kabupaten Bandung Barat kemampuan berpikir kreatif siswa masih kurang dilihat dari hasil analisis Tingkat Kemampuan Berpikir Kreatif (TKBK) siswa yang hanya mampu mencapai TKBK 2 yaitu cukup kreatif. Penelitian lainnya dilakukan Firdaus, As'ari, Qohar (2016:228) menunjukan bahwa kemampuan berpikir kreatif matematik siswa SMA masih kurang kreatif dalam menyelesaikan soal-soal kemampuan berpikir kreatif $75 \%$ siswa masih kurang lancar dan $25 \%$ siswa belum dapat menggunakan cara-cara yang berbeda dalam menyelesaikan soal.

\section{METODE PENELITIAN}

Metode yang digunakan dalam penelitian ini adalah metode kuasi-eksperimen, dimana pengambilan kelas tidak dilakukan secara acak melainkan ditentukan oleh pihak sekolah. Penelitian ini melibatkan dua kelas, yaitu kelas yang pembelajarannya menggunakan pendekatan Problem-Based Learning dan kelas yang menggunakan pembelajaran biasa. Pembelajaran biasa yang dimaksud dalam penelitian ini adalah pembelajaran yang biasa dilakukan oleh guru di kelas. Populasi dalam penelitian ini adalah seluruh siswa SMA di Kabupaten Bandung Barat sedangkan sampel dipilih dua kelas XI SMAN di Ngamprah. Instrumen dalam penelitian ini berupa tes tipe uraian yang terdiri dari lima butir soal dengan indikator kemampuan berpikir kreatif matematik, yaitu fluency, flexibility, originality, dan elaboration. Soal-soal yang digunakan untuk pretes dan postes adalah soal yang sama. Instrumen tersebut diujicobakan terlebih dahulu di kelas XII dan di SMA yang serupa.

\section{HASIL DAN PEMBAHASAN}

Sebelum diberikan perlakuan yang berbeda pada kedua kelas, yaitu kelas yang pembelajarannya menggunakan pendekatan Problem-Based Learning dan kelas yang menggunakan pembelajaran biasa, peneliti terlebih dahulu memberikan pretes pada kedua kelas tersebut. Setelah diberikan pretes, peneliti memberikan perlakuan yang berbeda pada kedua kelas sebanyak 8 kali pertemuan, dan dipertemuan selanjutnya peneliti memberikan tes akhir kepada kedua kelas tersebut. Adapun hasil analisis data deskripsi kedua kelas tersaji pada Tabel 1 berikut ini. 
Tabel 1. Kemampuan Berpikir Kreatif Matematik

\begin{tabular}{|c|c|c|c|c|c|c|c|}
\hline \multirow[t]{2}{*}{ Variabel } & & \multicolumn{3}{|c|}{ Pendekatan Problem-Based Learning } & \multicolumn{3}{|c|}{ Pembelajaran biasa } \\
\hline & & Pretes & Postes & Gain & Pretes & Postes & Gain \\
\hline Kemampuan & $\mathrm{N}$ & 29 & 29 & 29 & 29 & 29 & 29 \\
\hline \multirow{3}{*}{$\begin{array}{c}\text { Berpikir Kreatif } \\
\text { Matematik }\end{array}$} & $\bar{x}$ & 0,86 & 12,03 & 0,58 & 0,62 & 9,48 & 0,46 \\
\hline & $\%$ & 4,31 & 60,17 & & 3,10 & 47,41 & \\
\hline & $S$ & 0,64 & 2,58 & 0,14 & 0,82 & 2,37 & 0,11 \\
\hline & Tak & Ideal $\mathbf{K}$ & Ian Ber & reatif & ematik & h 20 . & \\
\hline
\end{tabular}

Berdasarkan data pada Tabel 1 diperoleh rata-rata pretes siswa yang pembelajarannya menggunakan pendekatan Problem-Based Learning dan siswa yang menggunakan pembelajaran biasa, dengan selisih untuk kedua kelas yaitu 0,24. Rata-rata pretes kemampuan berpikir kreatif matematik kedua kelas tersebut tidak jauh berbeda.

Pada Tabel 1 juga terlihat rata-rata postes siswa yang pembelajarannya menggunakan pendekatan Problem-Based Learning dan siswa yang menggunakan pembelajaran biasa, dengan selisih untuk kedua kelas yaitu 2,55. Hal tersebut menunjukkan bahwa kemampuan akhir berpikir kreatif pada kelas yang pendekatan ProblemBased Learning mengalami peningkatan. Nilai rata-rata siswa yang pembelajarannya menggunakan pendekatan Problem-Based Learning yaitu $55<\bar{x} \leq 70$. Berdasarkan interprestasi menurut Maya (2011) termasuk kategori yang sedang. Sedangkan nilai rata-rata siswa yang mendapatkan pembelajaran biasa yaitu $\bar{x}<55$, berdasarkan interpretasi menurut Maya (2011) termasuk kategori pencapaian yang rendah.

Berdasarkan tabel yang sama, rata-rata $N$ Gain kemampuan berpikir kreatif matematik siswa yang pembelajarannya menggunakan pendekatan Problem-Based Learning dan siswa yang menggunakan pembelajaran biasa, dengan selisih untuk kedua kelas yaitu 0,12. Dari data tersebut terlihat bahwa rata-rata $N$-Gain kelas yang pembelajarannya menggunakan pendekatan Problem-Based Learning lebih besar dibanding kelas yang menggunakan pembelajaran biasa. Besar $N$-Gain kedua kelas yaitu $0,30<(\mathrm{g})<$ 0,70. Berdasarkan interpretasi menurut Hake (Nurwulan, 2017:33) termasuk klasifikasi peningkatan yang sedang.
Tabel 2. Uji Dua Rata-rata Postes Kemampuan Berpikir Kreatif Matematik

\begin{tabular}{cr}
\hline \multicolumn{2}{c}{ Test Statistics $^{\mathbf{a}}$} \\
\hline \multicolumn{2}{c}{ Postes } \\
\hline Mann-Whitney U & 194,000 \\
\hline Wilcoxon W & 629,000 \\
\hline Z & $-3,580$ \\
\hline Asymp. Sig. (2-tailed) &, 000 \\
\hline
\end{tabular}

Berdasarkan Tabel 2 hasil perhitungan postes untuk kemampuan berpikir kreatif matematik menunjukkan nilai signifikansi dua pihak (sig. (2-tailed)) adalah 0,000. Berdasarkan nilai sig. (1-tailed) $<0,05$ dengan demikian $\mathrm{H}_{0}$ ditolak. Itu artinya pencapaian pada kemampuan berpikir kreatif matematik siswa SMA yang pembelajarannya menggunakan pendekatan Problem-Based Learning lebih baik daripada siswa yang menggunakan pembelajaran biasa.

Tabel 3. Uji Dua Rata-rata N-Gain Kemampuan Berpikir Kreatif Matematik

\begin{tabular}{cr}
\hline \multicolumn{2}{c}{ Test Statistics $^{\mathbf{a}}$} \\
\hline \multicolumn{2}{c}{ N_Gain } \\
\hline Mann-Whitney U & 207,500 \\
\hline Wilcoxon W & 642,500 \\
\hline Z & $-3,323$ \\
\hline Asymp. Sig. (2-tailed) &, 001 \\
\hline
\end{tabular}

Berdasarkan Tabel 3 hasil perhitungan tersebut menunjukkan nilai signifikansi dua pihak (sig. (2-tailed)) adalah 0,001, berdasarkan nilai sig.(1-tailed) $<0,05$ dengan demikian $\mathrm{H}_{0}$ ditolak. Artinya peningkatan pada kemampuan berpikir kreatif matematik siswa SMA yang pembelajarannya menggunakan pendekatan Problem-Based Learning lebih baik daripada siswa yang menggunakan pembelajaran biasa.

Berdasarkan analisis statistik deskriptif, terlihat bahwa nilai rata-rata pretes kedua kelas tidak terdapat perbedaan yang tidak terlalu jauh. Begitu juga dengan perhitungan statistik secara inferensial diperoleh kesimpulan bahwa tidak terdapat perbedaan kemampuan awal berpikir 
kreatif matematik siswa pada kelas yang pembelajarannya menggunakan pendekatan Problem-Based Learning dan kelas yang menggunakan pembelajaran biasa.

Setelah dilakukan perlakuan yang berbeda, kedua kelas diberikan postes untuk mengetahui perbedaan kemampuan berpikir kreatif matematik siswa yang pembelajarannya menggunakan pendekatan Problem-Based Learning dengan kelas yang menggunakan pembelajaran biasa. Pada analisis statistik desriptif, nilai rata-rata postes pada kelas yang pembelajarannya menggunakan pendekatan Problem-Based Learning lebih besar daripada kelas yang mendapatkan pembelajaran biasa. Jika ditinjau dari hasil penelitian peningkatan berpikir kreatif matematik siswa yang pembelajarannya mendapatkan pendekatan Problem-Based Learning kualifikasi nilai rata-rata postes tidak terlalu begitu signifikan dengan kelas yang menggunakan pembelajaran biasa. Hasil yang didapatkan oleh siswa tidak optimal, karena siswa dihadapkan dengan permasalahan-permasalahan yang tidak rutin. Begitu juga dengan perhitungan statistik secara inferensial diperoleh kesimpulan bahwa pencapaian kemampuan berpikir kreatif matematik siswa yang pembelajarannya menggunakan pendekatan Problem-Based Learning lebih baik daripada siswa yang mendapatkan pembelajaran biasa.

Pada analisis statistik desriptif, nilai ratarata $\mathrm{N}$-gain pada kelas yang pembelajarannya menggunakan pendekatan Problem-Based Learning lebih besar daripada kelas yang menggunakan pembelajaran biasa. Begitu juga dengan perhitungan statistik secara inferensial diperoleh kesimpulan bahwa peningkatan kemampuan berpikir kreatif matematik siswa yang pembelajarannya menggunakan pendekatan Problem-Based Learning lebih baik daripada siswa yang menggunakan pembelajaran biasa.

Pencapaian dan peningkatan kemampuan berpikir kreatif matematik siswa pada kelas yang pembelajarannya menggunakan pendekatan Problem-Based Learning lebih baik daripada kelas yang menggunakan pembelajaran biasa. Hal tersebut dipengaruhi oleh pembelajaran yang menyenangkan dan menuntut siswa aktif dalam proses pembelajaran serta antusias siswa selama pembelajaran sehingga siswa lancar dalam pembelajaran. Selain itu karena pembelajaran yang menggunakan pendekatan Problem-Based Learning menuntun siswa untuk memahami suatu konsep matematika melalui permasalahan yang diberikan di LKS, yang berkaitan dengan masalah yang autentik. Sehingga siswa mampu mengaitkan antara pengalaman dengan pengetahuan konsep baru yang didapatkannya melalui langkah-langkah dalam LKS yang mereka identifikasi sendiri serta siswa dapat menemukan ide-ide yang baru, unik dan berbeda dalam diskusi kelompok ketika menggerjakan LKS yang diberikan, dan bertukar pendapat untuk mengembangkan pengetahuan dalam menemukan konsep dari materi yang sedang dipelajari.

Berdasarkan hasil pembahasan di atas dapat diketahui bahwa kemampuan berpikir kreatif matematik siswa yang pembelajarannya menggunakan pendekatan Problem-Based Learning lebih baik daripada kelas yang menggunakan pembelajaran biasa biasa, hal ini sejalan dengan penelitian yang dilakukan oleh Ulger (2018) dengan judul The effect of problembased learning on the creative thinking and critical thinking disposition of students in visual arts education" yang menyimpulkan berdasarkan penelitiannya bahwa penelitian Problem Based Learning dapat membantu siswa dalam proses pemecahan masalah sehingga dengan pendekatan tersebut dapat meningkatkan kemampuan berpikir kreatif matematik siswa. Hal tersebut karena dalam pembelajaran dengan pendekatan ProblemBased Learning menggunakan masalah dunia nyata sebagai suatu konteks permasalahan. Selain itu, ditemukan produk kreatif siswa berupa pengerjaan soal dengan memberikan jawaban secara tepat dan benar.

\section{SIMPULAN}

Pencapaian kemampuan berpikir kreatif matematik siswa SMA yang pembelajaranya menggunakan pendekatan Problem-Based Learning lebih baik daripada siswa SMA yang menggunakan pembelajaran biasa, dengan kategori untuk kemampuan berpikir kreatif sedang. Peningkatan kemampuan berpikir kreatif matematik siswa SMA yang pembelajaranya menggunakan pendekatan Problem-Based Learning lebih baik daripada siswa SMA yang menggunakan pembelajaran biasa, dengan kategori untuk kemampuan berpikir kreatif sedang.

\section{DAFTAR PUSTAKA}

Arief, H. S., \& Sudin, A. 2016. Meningkatkan Motivasi Belajar Melalui Pendekatan Problem-Based Learning (Pbl). Jurnal Pena Ilmiah, 1(1) : 141-150.

Ayuni, R., Firmansyah, D., Senjayawati, E., \& Maya, R. 2018. Analisis Tingkat Kemampuan Berpikir Kreatif Siswa Dalam 
Adi Nurjaman dan Indah Puspita Sari

Anargya: Jurnal Pendidikan Matematika, Vol. 2 No.2, Oktober 2019

Menyelesaikan Permasalahan pada Materi Lingkaran. JURNAL MATHEMATIC PAEDAGOGIC, 2(2), 139-148.

Barrows, H. S., \& Tamblyn, R. M. 1980. Problem-based learning: An Approach to Medical Education. New York: Springer Publishing Company.

Firdaus, F., As' ari, A. R., \& Qohar, A. 2016. Meningkatkan Kemampuan Berpikir Kreatif Matematis Siswa SMA Melalui Pembelajaran Open Ended Pada Materi SPLDV. Jurnal Pendidikan: Teori, Penelitian, dan Pengembangan, 1(2), 227236

Hosnan, M. 2014. Scientifict and Contextual Approach in 21'st Century Learning. Pendekatan Saintifik dan Kontekstual dalam Pembelajaran Abad, 21. Bogor: Ghalia Indonesia.

Lince, R. 2016. Creative thinking ability to increase student mathematical of junior high school by applying models numbered heads Together. Journal of Education and Practice, 7(6) : 206-212.
Nurjaman, A., \& Sari, I. P. (2017). The Effect Of Problem Posing Approach Towards Students' Mathematical Disposition, Critical \&Amp; Creative Thinking Ability Based On School Level. Infinity Journal, 6(1) : 69 .

Rohaeti, E. E., Nurjaman, A., Sari, I. P., Bernard, M., \& Hidayat, W. (2019). Developing Didactic Design in Triangle and Rectangular Toward Students Mathematical Creative Thinking through Visual Basic for PowerPoint. Journal of Physics: Conference Series, 1157(4).

Ulger, K. 2018. The effect of problem-based learning on the creative thinking and critical thinking disposition of students in visual arts education. Interdisciplinary Journal of Problem-Based Learning, 12(1) : 3-6. 